p-ISSN. 2086-9029

e-ISSN. 2654-5675

Vol. 22 No. 2, HIm. 159-352, Desember 2020

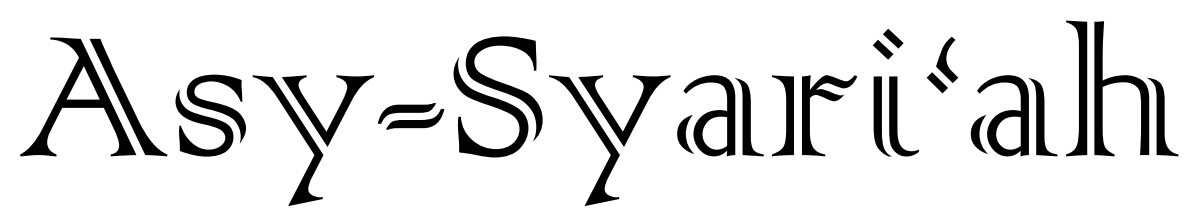

- Implementasi Prinsip Keadilan dalam Hukum Perjanjian Syari'ah

$(159-178)$ Zaenudin Mansyur

- Akad Rahn Tasyjili pada Gadai Tanah Pertanian di Pegadaian Syariah

$(179-196)$ Rahmadi Indra Tektona, Dyah Ochtorina Susanti

- Potensi Sertifikasi Halal dalam Mengahadapi Masyarakat Ekonomi

$(197-218)$ ASEAN

Deviana Yuanitasari, Helitha Noviana Dewi

- Akad Mudharabah sebagai Instrumen Pendanaan dan Pembiayaan di

$(219-236)$ Lembaga Keuangan Syariah

Asep Dadang Hidayat, Moh. Sar'an

- Praktik Rekayasa Dispensing Pump SPBU Persfektif Peraturan

$(237-258)$ Perundang-Undangan dan Hukum Islam

Hazar Kusmayanti, Ratu Chairunissa

- Dinamika Penerapan Akad Syariah dalam Produk Keuangan di Bank

$(259-274)$ Syariah

Jaenudin

- Etika Bisnis Islam pada Perilaku Pemasaran dan Kepuasan Konsumen

$(275-290)$ Wida Ramdania

- Kebijakan Fiskal Islam pada Masa Al-Khilafah Al-Islamiyah

Supriatna, Dedah Jubaedah

- Pelanggaran Prinsip Tanggungjawab Perusahaan Asuransi Investasi Persfektif Perundang-Undangan dan Hukum Ekonomi Syariah

Yoghi Arief Susanto, Yeti Sumiyati

- Identifikasi Kebutuhan Pembiayaan Syariah Peternak Lembu di Deli (337-352) Serdang

Marlya Fatira AK, Anriza Witi Nasution, Tuti Kurnia

FACULTY OF SHARIA AND LAW

STATE ISLAMIC UNIVERSITY SUNAN GUNUNG DJATI BANDUNG-INDONESIA IN COLLABORATION WITH ASOSIASI SARJANA SYARIAH INDONESIA 


\section{Asy-Syari'ah}

Volume 22, Number 2, 2020

\section{EDITOR-IN-CHIEF}

Ine Fauzia

\section{EDITORIAL BOARD}

Sofyan al-Hakim, UIN Sunan Gunung Djati Bandung, Indonesia Deni Kamaludin Yusup, UIN Sunan Gunung Djati Bandung, Indonesia

Meria Utama, Fakultas Hukum Univrsitas Sriwijaya, Indonesia

Dewi Mayaningsih, UIN Sunan Gunung Djati Bandung, Indonesia

Andrey Sujatmiko, Fakultas Hukum Universitas Trisakti, Jakarta, Indonesia

Hetty Hassanah, Universitas Komputer Indonesia, Indonesia

Tarun Ghawana, CDMS, New Delhi, India

Muhammad Hasanuddin, UIN Sunan Gunung Djati Bandung, Indonesia

Syahrul Anwar, UIN Sunan Gunung Djati Bandung, Indonesia

Aden Rosadi, UIN Sunan Gunung Djati Bandung, Indonesia

\section{PEER-REVIEWERS}

S. Salahudin Suyurno, Universiti Teknologi MARA (UiTM) Melaka, Malaysia

Ezani Yaakub, Universiti Teknologi MARA (UiTM) Malaysia, Malaysia

Zezen Zaenal Mutaqin, University of California, Los Angeles, United States

Muhammad Irfan Helmy, IAIN Salatiga, Semarang, Indonesia

Ahmad Ali Nurdin, UIN Sunan Gunung Djati Bandung

Tajul Arifin, UIN Sunan Gunun Djati Bandung, Indonesia

Mohamad Anton Athoillah, UIN Sunan Gunung Djati Bandung, Indonesia

Renny Supriyatni, Universitas Padjadjaran, Indonesia

Ahmad Tholabi Karlie, UIN Syarif Hidayatullah Jakarta, Indonesia

Ija Suntana, UIN Sunan Gunung Djati Bandung, Indonesia

Ahmad Fathonih, UIN Sunan Gunung Djati Bandung, Indonesia

Fauzan Ali Rasyid, UIN Sunan Gunung Djati Bandung, Indonesia

Rahman Syamsuddin, Universitas Islam Negeri Alauddin Makassar, Indonesia

\section{PROOFREADER/DESIGN COVER}

Nanang Sungkawa

\section{LAYOUT EDITOR}

Opik Rozikin

Asy-Syari'ah has been accredited by The Ministry of Education and Cultere, Republic of Indonesia as an academic journal in Sinta 3 (SK Diirjen Penguatan Riset dan Pengembangan Kemristekdikti No. 14/E/KPT/2019), valid for 5 years from Volume 19 No. 1 Tahun 2017 until Volume 23 No. 2 Tahun 2022. 


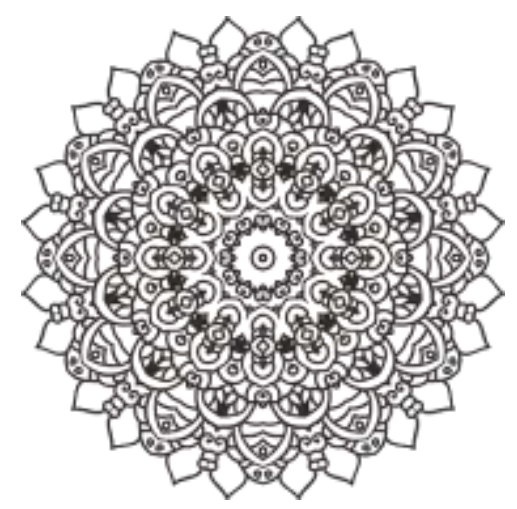

\title{
POTENSI SERTIFIKASI HALAL DALAM MENGHADAPI MASYARAKAT EKONOMI ASEAN (MEA)
}

\author{
${ }^{1}$ Deviana Yuanitasari, ${ }^{2}$ Helitha Novianty Muchtar \\ ${ }^{12}$ Fakultas Hukum, Universitas Padjadjaran \\ E-Mail: deviana.yuanitasari@unpad.ac.id helitha.novianty@unpad.ac.id
}

\begin{abstract}
Countries in various parts of the world are currently very concerned about the importance of an adequate standard of living with a sense of safety in the use of a product. Product quality is determined based on a standard of eligibility with evidence of a packaging label. The label is a guideline for determining the level of a product used. ASEAN as a single market and a unified production base, with free flow of goods, services, production factors, investment, and capital, as well as the elimination of tariffs for trade between ASEAN countries, is a reality that ASEAN countries, especially Indonesia, cannot negotiate. The movement of goods in ASEAN in free trade causes the Muslim community in Indonesia and other ASEAN countries to question the halalness of products that enter from abroad, therefore. This article aims to discuss the potential for halal certification in the scope of development of the ASEAN economic community market. This research method is normative juridical and analytical descriptive. The results show that halal certification for food products must be carried out, by taking into account the uniformity of requirements, labels, and registration in one application for registration of halal certification in ASEAN Countries ASEAN national cooperation related to halal certification such as the establishment of institutions (regional halal accreditation boards), the establishment of a single registration system. application, uniformity of requirements, halal standards, regional certification, the establishment of regulations, and approval in the field of halal certification are the right solutions today to provide convenience for business actors while ensuring the safety of halal products in Indonesia.
\end{abstract}

Keywords: Halal Certification; Registration; Asean Economic Community; Halal Label 
Abstrak: Negara-negara di berbagai belahan dunia saat ini sangat memperhatikan pentingnya standar kelayakan hidup yang memadai dengan rasa aman dalam penggunaan suatu produk. Mutu produk ditentukan berdasarkan standard kelayakan dengan bukti adanya label suatu kemasan. Label tersebut menjadi pedoman penentuan tinggi rendahnya suatu produk yang digunakan. ASEAN sebagai pasar tunggal dan kesatuan basis produksi, dengan free flow atas barang, jasa, faktor produksi, investasi dan modal, serta penghapusan tarif bagi perdagangan antar negara ASEAN menjadi sebuah realitas yang tidak dapat ditawar lagi oleh negara ASEAN khususnya Indonesia. Bergeraknya barang di ASEAN dalam perdagangan bebas membuat komunitas muslim di Indonesia dan negara ASEAN lainnya mempertanyakan kehalalan produk yang masuk dari luar negaranya, oleh karena itu artikel ini bertujuan untuk membahas tentang potensi sertifikasi halal dalam lingkup perkembangan pasar masyarakat ekonomi ASEAN. Metode penelitian ini adalah yuridis normative dan bersifat deskriptif analitis. Hasil penelitian menunjukan bahwa sertifikasi halal untuk produk makanan harus dilakukan, dengan meperhatikan keseragaman syarat, label dan pendaftaran dalam satu aplikasi untuk pendaftaran sertifikasi halal di Negara ASEAN. Kerjasama nagara ASEAN terkait sertifikasi halal seperti pembentukan lembaga (Dewan Akreditasi Halal Regional), pembentukan sistem pendaftaran satu aplikasi, keseragaman persyaratan, standar halal, sertifikasi regional, pembentukan peraturan dan persetujuan di bidang sertifikasi halal menjadi solusi yang tepat saat ini untuk memberikan kemudahan bagi para pelaku usaha sekaligus menjamin keamanan akan produk halal di Indonesia.

Kata-Kata Kunci: Sertifikasi Halal; Pendaftaran; Masyarakat Ekonomi Asean; Label Halal 


\section{Pendahuluan}

Bagi masyarakat muslim Indonesia, pengetahuan tentang halal dan haram mengenai sebuah produk adalah hal yang sangat penting. Dengan adanya label halal, masyarakat muslim dapat memastikan produk mana saja yang boleh mereka konsumsi, yaitu produk yang memiliki dan mencantumkan label halal pada kemasannya. Masyarakat muslim harus punya hak untuk mengetahui bahwa suatu produk memiliki label halal atau tidak, khususnya setiap produk yang beredar di Indonesia. Dengan adanya hak untuk mengetahui kehalalan suatu produk, dapat dipastikan keterjaminan produk yang diedarkan di Indonesia tidak hanya aman, juga sebagai rasa mawas diri masyarakat muslim terhadap produk-produk yang dipasarkan. Namun begitupun dalam perjalanannya, masyarakat muslim mempunyai persepsi yang berbeda dalam memutuskan membeli suatu produk. Sebagian ada yang tidak memperdulikan dengan kehalalan suatu produk, dan ada pula sebagian lainnya memegang teguh pada prinsip bahwa suatu produk harus ada label halalnya. ${ }^{1}$

Kehalalan suatu produk menjadi kebutuhan wajib bagi setiap konsumen, terutama konsumen muslim. Baik itu produk berupa makanan, obat-obatan maupun barang-barang konsumsi lainnya. Seiring besarnya kuantitas konsumen muslim di Indonesia, berdasarkan Global Islamic Economic Report ${ }^{2}$ pada tahun 2020 yang jumlahnya mencapai 232,5 juta jiwa atau $87,18 \%$ dari total populasi penduduk Indonesia, dengan sendirinya pasar Indonesia menjadi pasar konsumen muslim yang sangat besar. Halal saat ini bukan hanya penting untuk konsumen muslim namun juga penting untuk konsumen global karena kehalalan suatu produk dapat mencerminkan kualitas dari produk tersebut. ${ }^{3}$

Pada zaman sekarang, yang diikuti perkembangan teknologi ${ }^{4}$ proses pengolahan makanan minuman, kosmetika dan obat telah melibatkan proses yang kompleks dan mengandung aneka ragam bahan sehinggapermasalahan makanan, minuman obat kosmetika dan barang gunaan halal menjadi tidak seimbang, penetapan kehalalan suatu produk halal tidaklah mudah ${ }^{5}$. Kemajuan ilmu pengetahuan dan teknologi di bidang pangan dewasa ini menyebabkan semakin rumitnya menentukanmana yang halal dan mana yang haram. Produk-produk pangan olahan semakin banyak beredar juga

${ }^{1}$ Syaiful Amri, M. Jamil, Ardiansyah, Analisis Yuridis Kewenangan Majelis Ulama Indonesia dalam penyelenggaraan Jaminal Produk Halal, Fakultas Syari'ah dan Hukum UIN Sumatera Utara Medan, diunduh 7 maret 2020

${ }^{2}$ State of the Global Islamic Economy Report 2020/2021, Thomson Reuters, 2020

${ }^{3}$ Rokshana Shirin Asa, An Overview Of The Developments Of Halal Certification Laws In Malaysia, Singapore, Brunei And Indonesia, Jurnal Syariah, Jil. 27, Bil. 1 (2019) 173-200

${ }^{4}$ Idris, S.H., Abdul Majeed, A.B. \& Chang, L.W. Beyond Halal: Maqasid al-Shari'ah to Assess Bioethical Issues Arising from Genetically Modified Crops. Sci Eng Ethics 26, 1463-1476 (2020). https://remote-lib.ui.ac.id:2116/10.1007/s11948-020-00177-6

${ }^{5}$ Fuseini, A., Hadley, P. and Knowles, T. (2020), "Halal food marketing: an evaluation of UK halal standards", Journal of Islamic Marketing, Vol. ahead-of-print No. ahead-of-print. https://remotelib.ui.ac.id:2116/10.1108/JIMA-02-2020-0037 
membutuhkan penetapan kehalalannnya, tidak hanya dari bahan bakunya tetapi juga mencakup penyediaan bahan, pengolahan, penyimpanan, pengemasan, pendistribusian, penjualan, dan penyajian produk. Oleh karena itu dibutuhkan pengetahuan yang cukup memadai tentang pedoman atau standar hukum Islam

Gaya hidup, budaya, agama, diet dan pola hidup sehat biasanya dicerminkan dengan makanan yang dikonsumsi. Untuk komunitas muslim pemilihan makanan yang utama adalah kehalalannya, komunitas muslim mengikuti al-Quran dalam memilih makanan yang akan dikonsumsi, untuk makanan berupa daging untuk komunitas muslim jarang terjadi pemalsuan karena daging yang akan dikonsumsi umat muslim adalah daging yang segar dan dikenali tekstur dan bentuknya ${ }^{6}$.

Standardisasi adalah senjata dalam persaingan di pasar global, terutama dalam Masyarakat Ekonomi ASEAN (MEA). Standarisasi juga adalah sarana perubahan untuk menuju Indonesia yang lebih baik. Selain itu, standar juga sebagai piranti andal dalam perubahan sosial, ekonomi, budaya, serta mendukung regulasi seperti SNI tabung gas konversi minyak tanah ke gas.

Standarisasi harus dilakukan secara komperehensif, integral dan visioner. Karena standarisasi tidak dapat berdiri sendiri. ada tiga pilar infrastruktur mutu nasional dalam standarisasi yakni metrology, standarisasi, dan penilaian kesesuaian. Peningkatan daya saing di era globalisasi dan regionalisasi perdagangan tidak dapat dihindari lagi. Pada dasarnya hanya bangsa yang berdaya sainglah yang akan mampu memperoleh manfaat yang besar untuk meningkatkan kesejahteraannya. Yaitu untuk bangsa yang memiliki kemampuan untuk dapat diterima sebagai pemain dalam rantai produksi dan transaksi global dan regional. Sementara sebaliknya, bangsa yang tidak mampu meningkatkan daya saingnya akan menjadi korban dan hanya menjadi penonton tanpa memperoleh keuntungan ekonomi dari segala potensi perdagangan global tersebut.

Masyarakat Ekonomi Asean (MEA) memiliki lima pilar utama, yaitu aliran bebas barang (free flow of goods), aliran bebas jasa (free flow of sevice), aliran bebas investasi (free flow of investment), aliran bebas tenaga kerja terampil (free flow of skilled labour), dan aliran bebas modal (free flow of capital). ${ }^{7}$. MEA merupakan suatu integrasi dari negaranegara di kawasan Asia Tenggara yang bertujuan untuk memperkecil kesenjangan antara negara-negara ASEAN dalam hal pertumbuhan perekonomian. Beberapa hal menjadi fokus dari MEA, salah satunya adalah MEA dibentuk sebagai kawasan ekonomi dengan tingkat kompetisi yang tinggi. Untuk menjamin terciptanya tingkat persaingan yang tinggi dan adil, MEA membentuk sebuah kebijakan berupa perlindungan konsumen yang juga menjamin adanya arus informasi yang akurat di pasar barang dan jasa.

\footnotetext{
${ }^{6}$ Vandendriessche, F,"Meat products in the past, today and in the future" ,Meat Science Journal , vol.78, No.2, 104-113

${ }^{7}$ Kazushi Shimizu, "The ASEAN Charter and the ASEAN Economic Community", Economic Journal of Hokkaido University, Vol 40, 2011, hlm. 73-87
} 
Menciptakan ASEAN sebagai sebuah pasar tunggal dan kesatuan basis produksi, dimana terjadi free flow atas barang, jasa, faktor produksi, investasi dan modal serta penghapusan tarif bagi perdagangan antar negara ASEAN. Itu adalah sekilas yang dimaksud dengan MEA. MEA bertujuan untuk memperkecil kesenjangan antara negara-negara ASEAN dalam hal pertumbuhan perekonomian. ${ }^{8}$ Membentuk kawasan ekonomi antar negara ASEAN yang kuat. Kita tahu sekarang ini di Amerika dan Eropa masih mengalami krisis ekonomi. Dan dengan terbentuknya Masyarakat Ekonomi ASEAN diharapkan akan bisa mengatasi masalah-masalah dalam bidang perekonomian antar negara ASEAN.

Persaingan barang dan jasa antar negara ASEAN diuji dengan adanya MEA. Dengan maksud untuk menjadikan ASEAN sebagai kawasan perekonomian yang disegani oleh dunia dan memiliki pengaruh dalam perkembangan ekonomi dunia. Masyarakat Ekonomi ASEAN (MEA) menjadikan ASEAN sebagai pasar dan basis produksi tunggal dengan integrasi ekonomi yang membuat ASEAN semakin dinamis dan kompetitif dengan mekanisme yang dapat meningkatkan inisiatif ekonomi; mempercepat integrasi regional dalam sektor-sektor prioritas; memfasilitasi pergerakan bisnis, tenaga kerja terampil dan bakat; serta memperkuat kelembagaan ASEAN. Sebagai langkah awal untuk mewujudkan Masyarakat Ekonomi ASEAN. Dengan begitu maka MEA dapat membuat integrasi ekonomi serta mendorong investasi.

Dari semua komponen dasarnya perdagangan adalah standarisasi karena sebagai tolak ukur dalam perdagangan barang-barang khusunya dalam hal ekspor dan impor. Hal itu karena setiap negara mengharuskan adanya pengujian terhadap barang -barang yang akan diimpor maupun diekspor. Dalam masyarakat ASEAN harus ada standar yang memadai karena barang-barang berkualitas yang boleh menjelajah negara-negara lain. Standardisasi dalam Masyarakat Ekonomi Asean ditujukan untuk memudahkan dan melindungi ekspor impor barang sehingga barang tersebut bisa bersaing dengan Negaranegara lain. Selain standardisasi sertifikasi halal produk-produk makanan juga diperlukan dalam pergerakan pasar dan barang khususnya makanan di ASEAN.

Gaya hidup, budaya, agama, diet dan pola hidup sehat biasanya dicerminkan dengan makanan yang dikonsumsi. Untuk komunitas muslim pemilihan makanan yang utama adalah kehalalannya,komunitas muslim mengikuti al-Quran dalam memilih makanan yang akan dikonsumsi, untuk makanan berupa daging untuk komunitas muslim jarang terjadi pemalsuan karena daging yang akan dikonsumsi umat muslim adalah daging yang segar dan dikenali tekstur dan bentuknya?.

Sertifikasi halal adalah dokumen resmi yang memungkinkan produsen/Penjual atas

\footnotetext{
${ }^{8}$ Suppanunta Romprasert, "Asian Economic Community with Selected Macroeconomic Variables for Exports Sustainability", International Journal of Economics and Financial Issues, Vol. 3, No. 3, 2013, hlm. 602605,2013

${ }^{9}$ Vandendriessche, $F$,"Meat products in the past, today and in the future" ,Meat Science Journal , vol.78, No.2, 104-113
} 
beberapa barang untuk menampilkan halal logo pada produk dan pada titik penjualan operasi. Hanya mengetahui dan menerima produk sebagai halal tidak menjamin penggunaan logo yang halal. Salah satu harus pergi melalui proses yang ditetapkan ditentukan oleh instansi yang berwenang

Pendaftaran dan syarat sertifikasi halal di setiap Negara akan berbeda-beda, tetapi syarat utama nya akan sama hal ini dikarenakan persyaratan utama berasal dari Al Quran dan hadist, Proses utama ini bisa dijadikan dasar syarat utama pelindungan di ASEAN, sertifikasi halal untuk produk makanan sudah tidak bisa ditawar lagi oleh karena itu perlu satu keseragaman syarat, label dan pendaftaran dengan satu aplikasi untuk pendaftaran sertifikasi halal di Negara asean, Berdasarkan uraian diatas masalah yang diambil yakni bagaimanakah proses pendaftaran sertifikasi halal yang paling memadai dan efektif untuk produk makanan di ASEAN.

\section{Metodologi}

Metode penelitian yang digunakan merupakan yuridis normatif, yang meliputi penelitian inventarisasi hukum positif, penelitian terhadap asas-asas hukum dan penelitian hukum in concreto, penelitian sistematik hukum, penelitian sejarah hukum dan perbandingan hukum. ${ }^{10}$ Data yang digunakan merupakan data sekunder berupa bahan- bahan hukum primer, bahan hukum sekunder dan bahan hukum tersier. ${ }^{11}$ Penelitian ini bersifat deskriptif analitis, yaitu membuat pencaindraan secara sistematis mengenai fakta-fakta ${ }^{12}$ termasuk di dalamnya menggambarkan peraturan-peraturan dan kebijakan yang berlaku. ${ }^{13}$

\section{Potensi Sertifikasi Halal Untuk Masyarakat Ekonomi ASEAN Pengaturan Sertifikasi Produk Halal di Indonesia}

Penyelenggaraan jaminan produk halal di Indonesia saat ini telah diatur dalam Undang-Undang No. 33 Tahun 2014 Tentang Jaminan Produk Halal (UUJPH). Pemberlakuan UUJPH ini membawa perubahan mendasar terkait penyelenggaraan sertifikasi halal di Indonesia. Dengan pemberlakuan UUJPH ini penyelenggaraan sertifikasi halal yang sebelumnya dilaksanakan oleh LPPOM-MUI akan diambil alih oleh BPJPH. BPJPH ini merupakan badan yang dibentuk oleh pemerintah untuk menyelenggarakan jaminan produk halal di Indonesia ${ }^{14}$.

${ }^{10}$ Ronny Hanitijo Soemitro, 1990, Metodologi Penelitian Hukum dan Jurimetri, Ghalia Indonesia, Jakarta, hlm. 9-10.

${ }^{11}$ Soerjono Soekanto, et al., 2006, Penelitian Hukum Normatif suatu Tinjauan Singkat, Rajawali, Jakarta, hlm. 13-14.

${ }^{12}$ Ronny Hanitijo, Op Cit, hlm.22

${ }^{13}$ Sumadi, 1988, Metode Penelitian, Rajawali, Jakarta, hlm. 19.

${ }^{14}$ Susilowati Suparto, et all, Harmonisasi dan Sinkronisasi pengaturan kelembagaan sertifikasi halal terkait pelindungan konsumen muslim di Indonesia, Mimbar Hukum, Vol, No.28 No. 3 (2016), 428 
Sejarah sertifikasi halal pada awalnya terjadi ketika kasus lemak babi yang meresahkan masyarakat, untuk meredakannya pemerintah membentuk LPPOM-MUI, pemerintah dan masyarakat berharap MUI dapat menjadi solusi agar kasus lemak babi tidak terjadi lagi. LPPOM-MUI didirikan pada tanggal 6 Januari 1989 untuk melakukan pemeriksaan dan sertifikasi halal. ${ }^{15}$

Persyaratan halal didasarkan pada 2 hal yaitu syarat ketentuan halal berdasarkan agama (Quran) dan Persyaratan sertifikasi halal berdasarkan peraturan perundangundangan dari suatu Negara. Pada dasarnya semua produk makanan diizinkan kecuali yang dilarang secara eksplisit menurut hukum islam termasuk di dalamnya alkohol, daging babi, darah, daging dari mayat, dan daging hewan yang belum disembelih sesuai peraturan islam. ${ }^{16}$

Pemberlakuan Undang-Undang Jaminan Produk Halal (UUJPH) merupakan salah satu bentuk perlindungan dari negara kepada konsumen muslim di Indonesia. Untuk menjamin setiap pemeluk agama untuk beribadah dan menjalankan ajaran agamanya, negara berkewajiban memberikan pelindungan dan jaminan tentang kehalalan produk yang dikonsumsi dan digunakan masyarakat, khususnya masyarakat muslim.hal ini dinyatakan dalam Pasal Pasal 29 ayat (2) UUD 1945.

Pasal 1 angka 5 UUJPH menyatakan bahwa jaminan produk halal adalah kepastian hukum terhadap kehalalan suatu produk yang dibuktikan dengan sertifikat halal. Obyek sertifikasi halal yang diatur dalam UUJPH lebih luas tidak hanya berupa terkait dengan produk pangan. Hal ini dapat dilihat dari ketentuan Pasal 1 angka 1 UUPJH yang menyatakan bahwa produk yang disertifikasi meliputi barang dan/atau jasa yang terkait dengan makanan, minuman, obat, kosmetik, produk kimiawi, produk biologi, produk rekayasa genetik, serta barang gunaan yang dipakai, digunakan, atau dimanfaatkan oleh masyarakat.

Penyelenggaraan jaminan produk halal adalah tanggung jawab pemerintah, hal ini dinyatakan dalam Pasal 5 UUJPH Segala proses Penyelenggaraan jaminan produk halal ini dilaksanakan oleh Kementerian Agama. Untuk melaksanakan penyelenggaraan jaminan produk halal tersebut pemerintah membentuk Badan Penyelenggara Jaminan Produk Halal (BPJPH) yang memiliki kedudukan di bawah dan bertanggung jawab kepada Menteri Agama. BPJPH dalam penyelenggaraan jaminan produk halal diberikan kewenangan untuk menerbitkan dan mencabut sertifat halal dan label halal pada produk yang sebelumnya merupakan kewenangan LPPOM-MUI. Dengan pemberlakuan UUJPH ini secara kelembagaan, maka terjadi peralihan kewenangan dalam penerbitan serti kasi halal dari LPPOM-MUI kepada BPJPH. Sertifikat halal merupakan pengakuan kehalalan suatu

\footnotetext{
15 Majelis Ulama Indonesia, "Serti kat Halal MUI", http://www.halalmui.org/mui14/index.php/main/go_to_section/55/136o/page/1, diakses 15 Mei 2015.

${ }^{16}$ Bonne, K., \& Verbeke, W. Religious values informing halal meat production and the control and delivery of halal credence quality. Agriculture and Human Values, 25(1), 2008, P. 35-47
} 
produk yang dikeluarkan oleh BPJPH berdasarkan fatwa halal tertulis yang dikeluarkan oleh MUI.

Kementerian Agama telah membentuk Badan Penyelenggara Jaminan Produk Halal (BPJPH) yang merupakan amanat dari dari Undang-Undang Nomor 33 Tahun 2014. BPJPH itu digunakan untuk memberi jaminan dan perlindungan kepada masyarakat terkait kehalalan produk yang dikonsumsi dan digunakan masyarakat.

Pendaftaran sertifikasi halal di di Indonesia saat ini sudah melalui sistem online, system pendaftaran online ini dilindungi dengan system keamanan yang tinggi, terdapat 1700 auditor yang akan memeriksa produk untuk mendapatkan jaminan produk halal. Pemeriksaan dilakukan setelah semua syarat telah dilengkapi saat melakukan pendaftaran online. Pemeriksaan administrasi oleh BPJPH jika sudah rampung berkasnya akan dikirim ke Majelis Ulama Indonesia (MUI) Dari MUI kemudian MUI selaku pemegang fatwa halal ini, maka lalu MUI menyatakan halal atau tidak halal, lalu dikirim ke kementerian untuk diselesaikan. ${ }^{17}$

\section{Sertifikasi Halal Produk Makanan di ASEAN}

Untuk masyarakat muslim terutama di Indonesia, pengetahuan mengenai halal dan haram sebuah produk menjadi sangat penting. Dengan adanya label halal, masyarakat muslim dapat memastikan produk mana saja yang boleh mereka konsumsi, yaitu produk yang memiliki dan mencantumkan label halal pada kemasannya.. Dengan adanya hak untuk mengetahui kehalalan suatu produk, dapat dipastikan keterjaminan produk yang diedarkan di Indonesia tidak hanya aman, juga sebagai rasa mawas diri masyarakat muslim terhadap produk-produk yang dipasarkan. Walaupun dalam perjalanannya, masyarakat muslim memiliki persepsi yang berbeda dalam memutuskan membeli suatu produk. Sebagian ada yang tidak memperdulikan dengan kehalalan suatu produk, dan ada pula sebagian lainnya memegang teguh pada prinsip bahwa suatu produk harus ada label halalnya. ${ }^{18}$

Sertifikasi halal diterbitkan oleh Majelis Ulama Indonesia (MUI) yang berupa sertifikat halal dalam bentuk fatwa Majelis Ulama Indonesia berupa pernyataan kehalalan suatu produk makanan yang sesuai dengan syari'at islam. Pencantuman label halal pada kemasan produk makanan didasarkan pada sertifikat halal yang diterbitkan oleh MUI, dengan kata lain sertifikat Halal MUI merupakan syarat mutlak yang harus dipenuhi untuk mencantuman label halal.

\footnotetext{
${ }^{17}$ Noval Dhwinuari Antony, Kemenag: Rancangan PP Jaminan Produk Halal akan Jadi Landasan BPJH, Rabu 07 Maret 2018, 16:41, https://news.detik.com/berita/d-3903668/kemenag-rancangan-ppjaminan-produk-halal-akan-jadi-landasan-bpjh.

${ }^{18}$ Syaiful Amri, M. Jamil, Ardiansyah, Analisis Yuridis Kewenangan Majelis Ulama Indonesia dalam penyelenggaraan Jaminal Produk Halal, Fakultas Syari'ah dan Hukum UIN Sumatera Utara Medan, diunduh 7 maret 2018
} 
Sertifikasi halal MUI ditujukan pada produk pangan, obat-obatan, kosmetika dan produk lainnya untuk memberikan kepastian status kehalalan, sehingga dapat mententramkan batin konsumen dalam mengkonsumsinya ${ }^{19}$ Penyelenggaran Jaminan Produk Halal memiliki tujuan memberikan keamanan, kenyamanan, keselamatan dan kepastian ketersediaan produk halal bagi masyarakat, dalam praktiknya BPJPH bertanggung jawab kepada Menteri Agama.

BPJPH dalam penyelenggaran jaminan produk halal memiliki kewenangan antara lain merumusan dan mentapkan jaminan produk halal, menetapkan norma, standar, prosedur dan kriteria jaminan produk halal serta menerbitkan dan mencabut sertifikasi halal dan label halal. ${ }^{20}$ BPJPH dalam melaksanakan kewenangannya itu bekerjasama dengan kementerian dan/atau lembaga terkait, Majelis Ulama Indonesia (MUI) dan Lembaga Pemeriksa Halal (LPH). Proses sertifikasi halal yang dilakukan di MUI, pada dasarnya dilaksanakan oleh LPOM-MUI. Proses serti kasi halal, mulai pendaftaran, pemeriksaan dan pengujian produk sampai dengan penerbitan serti kat halal suatu produk menjadi kewenangan LPPOM-MUI.

Secara umum prosedur sertifikasi halal adalah sebagai berikut : ${ }^{21}$ 1) Perusahaan yang mengajukan serti- kasi, baik pendaftaran baru, pengem- bangan (produk/fasilitas) dan perpanjangan, dapat melakukan pendaftaran secara online. LPPOM-MUI melalui website. 2) Mengisi data pendaftaran: status serti kasi (baru/pengembangan/per- panjangan), data serti kat halal, status Sistem Jaminan Halal (jika ada) dan kelompok produk. 3) Membayar biaya pendaftaran dan biaya akad serti kasi halal. 4) Mengisi dokumen yang dipersyaratkan dalam proses pendaftaran sesuai dengan status pendaftaran (baru/ pe-ngembangan/ perpanjangan) dan proses bisnis (industri pengolahan, $\mathrm{RPH}$, restoran, dan industri jasa), diantaranya: Manual Sistem Jaminan Halal, diagram alir proses produksi, data pabrik, data produk, data bahan dan dokumen bahan yang digunakan, serta data matrix produk. 5) Setelah selesai mengisi dokumen yang dipersyaratkan, maka tahap selanjutnya sesuai dengan diagram alir proses serti kasi halal seperti diatas yaitu pemeriksaan kecukupan dokumen.

Era perdagangan bebas masyarakat Ekonomi Asean (MEA) membuat Indonesia menjadi tujuan dalam perdagangan produk-produk asing, sertifikasi halal merupakan hal yang penting dalam peredaran obat dan makanan di Indonesia, dalam era perdangan bebas ini sertifikasi halal dinilai masih belum memadai dan meyakinkan karena masingmasing Negara di ASEAN memiliki lembaga sendiri untuk memberikan sertifikasi halal. Banyaknya barang import makanan dari Negara asean memmberikan kekhawatiran bagi

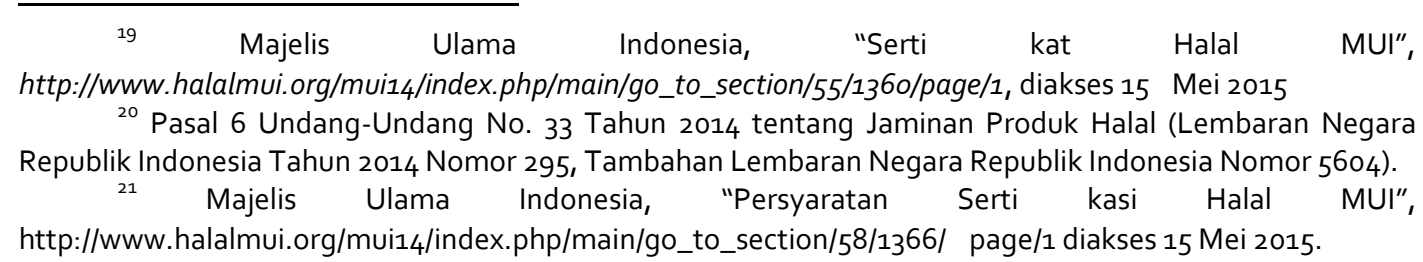


masyarakat muslim khususnya di Indonesia.

Produk makanan dari Malaysia dengan logo halal Malaysia, terdapat logo halal di dalamnya dengan logo halal Malaysia tidak dari Majelis ulama Indonesia (MUI), meskipun sertifikasi ini sama sertifikasi halal, tetapi kita tidak tahu bagaimana proses sertifikasi halal di Malaysia dan Negara-negara lain. ${ }^{22}$

\section{Penyelenggaraan Sertifikasi Halal di Malaysia}

Di Malaysia, yang berwenang untuk mengeluarkan Sertifikasi dan Label Halal adalah JAKIM $^{23}$. Posisi JAKIM ada di bawah Perdana Mentri langsung (Full under government) yaitu di bawah Prime Ministry Department yang langsung di bawah Sultan. Sertifikasi halal di Malaysia dimulai tahun 1974, UU pertama tahun 1975 yaitu Trade Description Act, awalnya yang menangani mengenai sertifikasi halal di tingkat Federal adalah JAKIM, dan di tingkat state adalah JAIM, kemudian baru pada tahun 2005 ada sinkronisasi kelembagaan dan pada akhirnya tahun 2010 selesai, sehingga saat ini yang berwenang menangani sertifikasi halal adalah JAKIM.

Di Malaysia tidak ada kewajiban bagi pelaku usaha untuk memeriksakan produknya untuk disertifikasi, tetapi apabila pelaku usaha yang sebetulnya belum mendapat sertifikasi halal namun sudah menggunakan logo halal maka dia harus membuktikan bahwa produknya halal, apabila ternyata produknya tidak halal maka pelaku usaha harus membayar uang penalty sebesar RM 1,5 juta dan kasus tersebut dapat diajukan ke Mahkamah Trade.

Untuk perolehan sertifikasi halal dari mulai pengajuan sampai terbit sertifikasi halal di Malaysia rata-rata memakan waktu 1 bulan, dengan jangka waktu maksimal 6 bulan. Biaya ditanggung oleh Kerajaan, namun pelaku usaha dikenai charge, charge tersebut akan berbeda-beda tergantung industrinya, untuk industry kecil dan menengah dikenai RM 100 per tahun, untuk multinational company sekitar RM 400 per tahun.

\section{Penyelenggaraan Sertifikasi Halal Brunei Darussalam}

Negara Brunei Darussalam memiliki Brunei" "Guideline For Use of The Brunei Halal Brand" yang dibuat oleh Jawatankuasa Pembangunan Standard Halal Kebangsaan dan Garis Panduan untuk Makanan Halal yang mengatur mengenai prosedur sertifikasi halal.

22 Dian Ihsan Siregar, BPOM Ragukan Peredaran Produk Halal di Perdagangan Bebas MEA, http://ekonomi.metrotvnews.com/mikro/yNLy1p2b-bpom-ragukan-peredaran-produk-halal-diperdagangan-bebas-mea, diunduh 7 maret 2018

${ }^{23}$ Chon Lok Siaw dan Nazayul Shima Abdul Rani, A Critical Review on The Regulatory and Legislation Challenges Faced by Halal Start up SMEs Food Manufacturers in Malaysia (Procedia-Social and Behavioral Sciences, Vol 57, 2012)

${ }^{24}$ Economic Research Institute for ASEAN and East Asia, Study on Halal Industry Investment in Brunei Darussalam, Final Report August 2016. 
Dinyatakan di dalam Guidelines tersebut bahwa apabila ada pelaku usaha yang melanggar peraturan di dalam guidelines tersebut akan dikenai sanksi yaitu berupa denda tidak melebihi $\$ 8000$ atau dihukum penjara tidak melebihi 2 tahun. Kesalahan-kesalahannya berupa masih menggunakan label halal yang sudah lewat masa waktunya, menghalangi pegawai penguatkuasa, kegagalan mematuhi perintah dan lain-lain.

Brunei Darusalam juga memiliki AKta Daging Halal (Penggal 183) serta aturanaturan di bawahnya seperti perintah Aturan-Aturan Daging Halal Pindaan (2008). Di Dalam Akta Daging Halal ini dinyatakan beberapa syarat penting seperti soal pengimporan daging halal yaitu daging tersebut harus diimpor dari Negara-negara yang bebas dari penyakit-penyakit berbahaya. Di dalam Bab 5 Pasal 4 akta ini menyatakan bahwa "Apabila sijil halal dikeluarkan berkaitan dengan mana-mana daging, tanda halal hendaklah dipamerkan pada daging tersebut oleh pembekal, tanda halal hendaklah terus dipamerkan semasa daging tersebut dijual" Apabila pelaku usaha melanggar ketentuan ini maka hukumannya adalah penjara tidak melebihi 1 tahun dan denda tidak melebihi \$ 4000 dan jika kesalahan kedua adalah penjara tidak melebihi 2 tahun atau denda tidak melebihi \$ 8000 dan Mahkamah berhak membatalkan sertifikasi halal.

\section{Penyelenggaraan Sertifikasi Halal di Singapura}

Singapura memberikan kewenangan mengenai sertifikasi halal di bawah Majelis Ugama Islam Singapura (MUIS) ${ }^{25}$. Pengaturan ini ada di dalam Akta Pentadbiran UndangUndang Orang Islam 1968 (AMLA). AMLA memberikan kuasa penuh hanya kepada MUIS dalam hal sertifikasi halal dan lembaga atau badan lain tidak dibenarkan. Di dalam Pasal 88A (5) dinyatakan bahwa apabila pelaku usaha yang belum lulus sertifikasi halal telah menggunakan label halal sebelumnya di dalam produknya maka akan dikenakan denda tidak melebihi SGD 10.000 atau penjara tidak melebihi 12 bulan. MUIS juga memiliki kuasa untuk membatalkan kelulusan sertifikasi halal kepada pelaku usaha apabila sekiranya gagal mematuhi syarat-syarat yang ditetapkan.

MUIS juga menggunakan The Singapore MUIS Halal Standards (SMHS) yang mana dua skop utama yaitu General Guidelines for the Handling and Processing of Halal Food (MUIS-HC-Soo1) dan General Guidelines for the Development and Implementation of a Halal Quality Management System (MUIS-HC-Soo2). Kedua komponen ini adalah yang berkaitan dengan masalah agama dan prosedur di dalam sertifikasi halal di Singapura.

${ }^{25}$ Zulzaidi Bin Mahmod, Pelaksanaan Pemantauan dan Penguatkuasaan Undang-Undang Produk Halal di Malaysia : Kajian Terhadap Penyalahgunaan Logo Halal, Tesis, Jabatan Syariah dan Undang-Undang Akademi Pengajian Islam, University Malaya, Kuala Lumpur 2011, hlm 152 


\section{Penyelenggaraan Sertifiaksi Halal di Thailand}

Untuk membuktikan Negara yang ramah terhadap wisatawan Muslim, pemerintah Thailand ${ }^{26}$ serius dalam menyediakan makanan halal di sejumlah restoran dan rumah makan. Proses sertifikasi halal tersebut dilakukan dengan prosedur yang ketat sesuai dengan syariah Islam.

President of The Foundation of Islamic Center of Thailand, Pakorn Priyakorn mengungkapkan,bahwa untuk mendapatkan sertifikasi halal, produk masakan akan diuji secara ketat di laboratorium salah satu perguruan tinggi di Thailand. Proses tersebut dimulai dari sampel makanan, bahan makanan, zat-zat yang terkandung di dalamnya, hingga tempat makanan tersebut berasal "Semuanya akan dilakukan pemeriksaan di laboratorium sampai benar-benar bisa dipastikan semuanya halal. Setelah itu, baru bisa mengeluarkan sertifikasi halal. Tidak hanya halal, makanan yang diperiksa di laboratorium tersebut juga harus bisa dipastikan kesehatannya. Dengan demikian, makanan tersebut sesuai dengan standar yang ditetapkan Alquran, yakni "halalan toyyiban" atau halal dan baik.

Berdasarkan data sensus penduduk yang dilakukan oleh Central Intelligence Agency (CIA) pada tahun 2010 hingga 2015 menunjukan bahwa jumlah total penduduk muslim ASEAN sekitar 256.250.448 jiwa dari total jumlah penduduk ASEAN sebanyak 634.875 .762 jiwa atau sekitar $40.4 \%$ penduduk muslim ASEAN. Jumlah tersebut menyebar di semua Negara ASEAN, seperti Indonesia (87.2\%), Brunei Darussalam (78.8\%), Malaysia (61.3\%), Laos (31\%), Singapore (14.3\%), Philiphina (5\%), Thailand (4.9\%), Myanmar (4\%), Kamboja (1.9\%), dan Vietnam (0.1\%). Jumlah tersebut akan terus meningkat sesuai dengan proyeksi yang dilakukan oleh Pew Research Center's Forum on Religion and Public Life bahwa total penduduk muslim dunia akan meningkat dari 1.6 milyar jiwa pada tahun 2010 menjadi 2.2 milyar jiwa pada tahun $2030 .{ }^{27}$

State of the Global Islamic Economy Report melakukan sebuah analisis pada tahun 2013 yang menyatakan bahwa Indonesia merupaka Negara dengan jumlah pengeluaran tertinggi untuk konsumsi pangan halal yaitu senilai 197 Milyar US Dollar. Sedangkan Malaysia menjadi Negara dengan total import daging sebesar 0.80 Milyar US Dollar. Hal tersebut menunjukan bahwa mayoritas Negara ASEAN membutuhkan industri pangan halal untuk memenuhi kebutuhan pangan negaranya. Potensi tersebut dapat dijadikan sebagai salah satu bentuk kerjasama regional dalam rangka Masyarakat Ekonomi Asean

\footnotetext{
${ }^{26}$ Hashem Salarzadeh \& Che wan Jasimah, Halal Food Industry in Thailand: History, Prospects and Challenges, Conference: The 1st International Halal Management Conference (Ihmc) 2017; Seoul, Korea

${ }^{27}$ Beastudi Indonesia, Halal Village sbagai Bentuk Sentralisasi Industri Pangan Asean dalam kerjasama Masyarakat Ekonomi ASEAN (MEA), https://www.beastudiindonesia.net/halal-village-sebagaibentuk-sentralisasi-industri-pangan-asean-dalam-kerjasama-masyarakat-ekonomi-asean-mea/, diunduh 7 maret 2018
} 
$(\mathrm{MEA})^{28}$. Dalam data yang diambil dari ASEAN Community: Regional Strategies to Tap Global Halal Business Opportunities yang dinyatakan dalam diagram dibawah ini : ${ }^{29}$

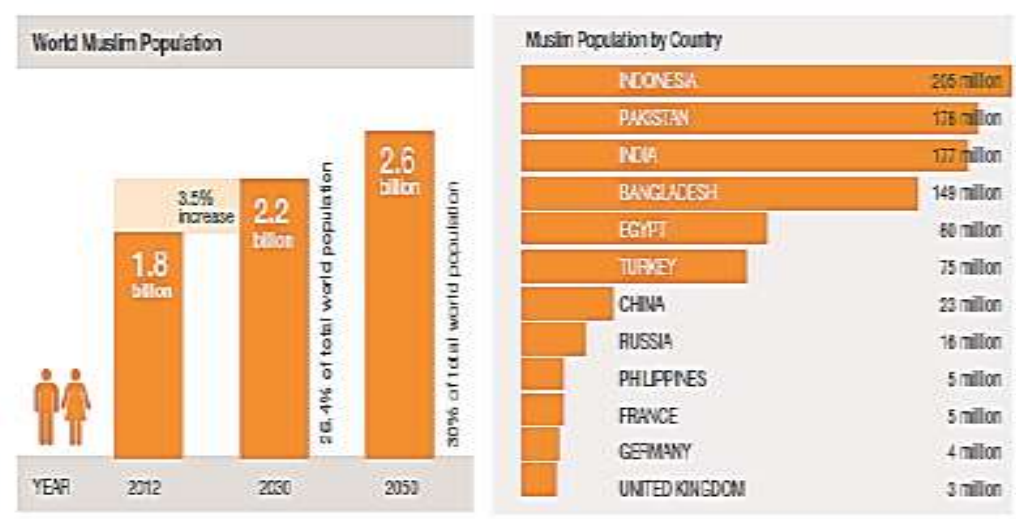

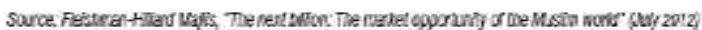

\section{Gambar. 1 ASEAN Community: Regional Strategies to Tap Global Halal Business Opportunities}

Komunitas muslim di asean akan meningkat hingga tahun 2050, kenaikan komunitas muslim tersebut komuitas muslim di asean paling banyak terdapat di Indonesia, dari data tersebut jumlah nya mencapai 205 million, kenaikan komunita muslim akan berkorelasi dengan makanan dan produk halal yang pasti akan dibutuhkan komunitas muslim tersebut. Dari angka kenaikan komunitas muslim di ASEAN dibutuhkan system baru dan terintegrasi yang memudahkan pendaftaran label halal di wilayah ASEAN, pendaftaran ini haruslah terintegrasi agar memudahkan pendaftaran sertifikasi halal untuk produk-produk yang beredar di wilayah ASEAN.

\section{Pendaftaran Satu Aplikasi Sertifikasi Halal di Wilayah ASEAN}

Negara-negara ASEAN merupakan pemasok terkemuka dan importir halal bersertifikat produk di dunia. Ada juga perdagangan intra-ASEAN substansial dalam makanan halal. Pemasok produk halal di dunia adalah Negara-negara ASEAN, produk import di seluru dunia didatangkan dari ASEAN, produk import yang terbesar adalah makanan halal. ${ }^{30}$

\section{${ }^{28}$ ibid}

${ }^{29}$ Pushpanathan Sundram Managing Director, Asia Pacific, EAS Strategies, ASEAN Community: Regional Strategies to Tap Global Halal Business Opportunities, 21 September 2015, http://www.thehalalfood.info/upload/articles/ASEAN_Pushpanathan.pdf

${ }^{30}$ Baharusdin Othman, Sharifudin Md. Shaaran and Arsiah Bahron, The Potential Of ASEAN in halal Certification Implementation: A Review, Pertanika JournalSocial Science and Humanities, Vol 24 (1), 2016, p. 20 
Singapura merupakan pusat transit utama di Asia Pasifik untuk makanan halal. ASEAN juga merupakan pemasok untuk Timur Tengah dengan penduduk Muslim 127 juta. Sebagian besar dari 80\% dari kebutuhan pangan yang bersumber dari luar negeri. Cina dengan 33 juta Muslim adalah pasar yang penting. Cina impor di sekitar US\$1,3 produk halal dari Malaysia sendirian. Cina sekarang adalah mitra dagang atas ASEAN, Eropa adalah pasar yang penting mengalami lonjakan permintaan. Perancis memiliki pasar halal terbesar dari sekitar US\$17b dan Inggris sekitar US\$4.2b. Eropa Timur adalah pasar lain untuk tekan. ${ }^{31}$

Pelaksanaan sertifikasi halal di Negara-negara ASEAN cukup beragam dan unik karena pelaksanaan sertifikasi halal di beberapa Negara ASEAN ada yang dikelola oleh pemerintah atau badan yang ditunjuk oleh pemerintah dan ada juga sebuah badan yang berdiri sendiri secara sukarela. Perbedaan dari proses sertifikasi di ASEAN adalah kemampuan teknologi melalui penelitian yang dilaksanakan oleh badan sertifikasi halal di Negara-negara ASEAN, ditemukan bahwa Malaysia, Indonesia, Singapura, Thailand dan Brunei yang lebih maju daripada Filipina dan Vietnam dalam bidang sertifiikasi halal.

Negara-negara ASEAN saat ini memiliki potensi besar dan sudah tidak diragukan lagi dalam hal sertifikasi halal, dalam praktiknya terdapat empat bidang utama dalam sertifikasi halal, ke empat hal tersebut adalah referensi standar halal, industry maju berbasis halal, pusat pelatihan keahlian, sistem uji halal dengan menggunakan teknologi, sertifikasi halal tidak terpaku hanya pada keuangan syariah dan investasi syariah, tapi mencakup semua aspek termasuk makanan, perlengkapan, obat-obatan, logistik dan lain-lain

ASEAN telah menjadi acuan dan referensi bagi organisasi-organisasi halal di seluruh dunia, hal ini diketahui karena standar halal yang di gunakan di banyak Negara ASEAN dijadikan panduan untuk insutri di Negara-negara lain di dunia. Misalnya Indonesia sebagai negara berkembang dibandingkan dengan negara-negara ASEAN lainnya dalam memperkenalkan sistem jaminan Halal telah menjadi referensi oleh berbagai negara di seluruh dunia seperti lembaga Islam di Kanada, Perancis dan seterusnya. Majunya industri berbasis halal dan adanya standardisasi halal didukung oleh proses kerja dan terpadu dari berbagai instansi pemerintah, terutama menguntungkan untuk industri halal antara negara-negara di ASEAN.

Setiap Negara khususnya Negara ASEAN memiliki spesifikasi, target dan standar tersendiri dalam hal masalah keaslian, peraturan label dan komposisi. Namun, hukum makanan Islam universal dan berasal dari Alquran, yang membuatnya mirip di semua negara di dunia ${ }^{32}$.

${ }^{31}$ ibid

$3^{2}$ Khadijah Nakyinsige a,d, Yaakob Bin Che Man a,b,Awis Qurni Sazili c," Halal authenticity issues in meat and meat products", Meat Science Journal, vol.91 (2012),211-212 
Syarat mendasar yang banyak digunakan untuk sertifikasi halal di berbagai negara adalah sebagai berikut ${ }^{33}$ : 1) Tidak Mengandung unsur-unsur yang tidak diperbolehkan menurut ajaran Islam. 2) Belum pernah kontak dengan zat terlarang/tidak diperbolehkan selama produksi, transportasi dan penyimpangan. 3) Tidak sisimpan di tempat atau diangkut dengan menggunakan kendaraan yang tidak diperbolehkan.

Untuk memastikan bahwa industri makanan telah memenuhi persyarakat dalam memproduksi makanan halal, produksi halal harus diverifikasi. Sertifikat dan pelabelan diperlukan untuk menunjukkan kepada konsumen dan pembeli bahwa prosuk diproduksi sesuai dengan metode sertifikasi halal. ${ }^{34}$

Logo halal merupakan salah satu atribut ${ }^{35}$ yang yang dipergunakan dalam pemilihan produk bagi masyrakat muslim di ASEAN, Penyeragaman logo/ lebel sertifikasi halal untuk wilayah ASEAN dan Logo Negara dimana produk dijual merupakan faktor penting yang harus dilakukan, keseragaman logo halal ASEAN dan Logo halal Negara akan mereduksi dan mengurangi kebingungan konsumen terhadap suatu produk bahan makanan.

Pedoman sertifikasi halal ASEAN dilaksanakan melalui skema akreditasi yang beroperasi di setiap Negara anggota. Dalam praktiknya pabrik pengelolaan makanan yang ingin diakui oleh ASEAN sebagai perusahaan halal harus mematuhi peraturan dan syarat yang diberikan oleh ASEAN. Setelah terakreditasi ASEAN perusahaan tersebut diizinkan menggunakan logo halal yang sama pada labelnya. Beranjak dari pedoman yang diterapkan ASEAN harus ada system akreditasi yang memadai dan memudahkan perusahaan di wilayah ASEAN untuk mendapatkan sertifikasi Halal baik sertifikasi halal ASEAN maupun sertifikasi halal di setiap Negara. Sistem pendaftaran satu pintu dan satu aplikasi akan memudahlan bagi perusahaan atau pelaku usaha baik dari dalam maupun luar negeri, Negara boleh menetapkan persyaratan tambahan selain syarat wajib yang ditetapkan pada pedoman sertifikasi halal ASEAN tetapi pendaftaran dapat dilakukan dengan satu aplikasi pada satu Negara saja (one application System).

Sistem pendaftaran satu aplikasi sertifikasi halal merupakan satu sistem pendataran yang dirancang untuk memfasilitasi proses perolehan sertifikasi halal di beberapa Negara ASEAN. Sistem ini mirip sistem PCT (patent Cooperation Treaty) sistem pendafatran paten yang telah diterapkan dan berhasil meningkatkan pendaftaran paten internasional. ${ }^{36}$

33 Ceranic, S., \& Bozinovic, N. (2009). Possibilities and significance of HAS implementation (halal assurance system) in existing quality system in food industry. Journal Biotechnology in Animal Husbandry, $25(3 / 4), 261-266$

${ }^{34}$ M.Van der Spiegel, H.J.van Der Fels-Klerx, P. Sterrenburg, S.M.Van Ruth, IMJ. Scholtens-Toma and E.J. Kok, Halal Assurance In food Supply Chain: Verification of Halal certificates Using Audits and Laboratory Analisis, Trends in Food Science \& technology 27, 2012, P.109-119

${ }^{35}$ Shafiq, A, Haque, A.K.M. and Omar, A, Multiple Logos and malay's beliefs : a case of Mix Signal, International Food Research Journal, Vol 22 (4), 2015, P.1727-1735

${ }^{36}$ PCT adalah suatu sistem global yang dirancang untuk memfasilitasi proses perolehan perlindungan paten di banyak Negara. Misalnya, inventor (penemu) atau perusahaan A ingin mendapatkan perlindungan paten di Jerman, Inggris, Amerika, Korea Selatan atau Jepang dsb, maka dia hanya cukup mengajukan satu 
Dalam sistem pendaftaran satu aplikasi sertifikasi halal, perusahaan hanya mendaftar kepada satu lembaga sertifikasi halal di negaranya, dalam pendaftaran tersebut lembaga sertifikasi halal memberikan pilihan: 1) Pendaftaran pada lembaga akreditasi halal regional ${ }^{37}$, dalam pendaftaran sertifikasi halal regional jika sudah terdaftar perusahaan (pendaftar) akan mendapatkan logo halal $A_{S E A N}{ }^{38}$. 2) Pendaftaran di Negara mana saja perusahaan (pendaftar) akan mendaftarkan produk halalnya.

Proses selanjutnya, setelah pendaftar mendaftarkan melalui kantor halal di negaranya, kantor halal akan memproses: 1) Memeriksa pendaftaran aplikasi halal yang dimintakan kepada negaranya, sesuai dengan panduan dan standar sertifikasi dimana kantor halal berada. 2) Mengirimkan berkas aplikasi pendaftaran halal (baik pendaftaran pada lembaga akreditasi halal regional maupun pendataran untuk beberapa Negara) kepada lembaga akreditasi halal regional. 3) Lembaga akreditasi halal regional meneruskan aplikasi pendaftaran tersebut kepada Negara-negara ASEAN yang dmintakan pendaftarannya.

Dalam satu aplikasi pendaftaran yang dikirim dari Negara asal,Lembaga akreditasi halal regional akan memeriksa kehalalan produk yang dimintakan pendaftarannya sesuai standar lembaga tersebut lalu mengeluarkan sertifikat dan izin penggunaan logo halal ASEAN, selain itu Lembaga akreditasi halal Regional juga meneruskan pendaftaran sertifikasi halal kepada kantor halal Negara-negara yang dimintakan pendaftarannya. Setelah kantor halal masing-masing Negara tersebut memeriksa dan mengeluarkan sertifikat halal serta izin penggunaan logo halal masing-masing Negara, kantor halal akan memberikan hasil pemeriksaan, sertifikat dan izin penggunaan logo halal Negara, selanjutnya lembaga akreditasi halal regional yang akan memberikan hasilnya kepada kantor/lembaga halal dimana pendaftaran dilakukan.

Dengan kata lain Untuk sertifikasi halal di berbagai Negara ASEAN yang dipilih, prosedur sertifikasi halal dilakukan sesuai syarat dan alur proses sertifikasi halal di Negara tersebut, setelah selesai pemeriksaan badan sertifikasi halal Negara tersebut dapat mengirimkan hasilnya kepada badan sertifikasi halal dimana aplikasi diajukan.

permohonan melalui $\mathrm{PCT}$, tidak perlu lagi mengajukan permohonan perlindungan paten ke masing-masing negara tersebut.Dengan fasilitas PCT, biaya yang dikeluarkan untuk mendapatkan perlindungan internasional atas paten di banyak negara relatif murah serta hemat dari segi waktu bila dibandingkan individu atau pengusaha swasta mengajukan permohonan perlindungan paten ke masing-masing Negara, Suwantin Oemar, Untuk dapatkan paten internasional : PCT buka jalan bagi negara berkembang, 11 April, 2005, http://www.haki.lipi.go.id/utama.cgi?cetakartikel\&1113176773

${ }^{37}$ Plan Of Action (Poa) For The Asean Cooperation In Halal Food (2017-2020), adopted 39 th AMAF Meeting, 28 September 2017, http://asean.org/storage/2012/05/2.-PoA-ASEAN-Halal-Cooperation-2020.pdf

${ }^{38}$ ASEAN Cooperation in Food, Agriculture and Forestry, Asean general Guidelines On The Preparation and Handling of Halal Food, Food Handling Publication Series No.1, http://www.asean.org/storage/images/Community/AEC/AMAF/UpdateApr2014/ASEAN\%20GENERAL\%20G UIDELINES\%20ON\%20HALAL\%2OFOOD_.pdf 
Dengan proses pendaftaran satu aplikasi dan adanya keseragaman logo sertifikasi halal ASEAN maka diharapkan akan mempermudah produsen makanan yang akan mendistribusikan produknya ke seluruh wilayah ASEAN, dengan begitu kepentingan produsen terpenuhi dan kepentingan konsumen akan terjaminnya logo halal juga akan terpenuhi.

Sebagai contoh jika perusaan Indonesia ingin akreditasi untuk sertifikasi halal, perusahaan dapat datang atau online pada lembaga sertifikasi halal di Indonesia tetapi dalam pengisian aplikasi tersebut perusahaan dapat langsung pula daftar untuk sertifikasi halal ASEAN sekaligus Sertifikasi halal diberbagai Negara yang dipilih, missalnya perusahaan tersebut ingin mendapatkan sertifikasi halal di Malaysia dan Brunei, maka perusahaan dapat mengisi aplikasi dan memenuhi persyaratan tambahan yang ditetapkan di Malaysia dan brunei.

Proses menuju system pendaftaran produk halal dalam satu aplikasi diperlukan beberapa langkah multilateral yang harus dibangun dan dilakukan oleh Negara ASEAN, hal yang paling utama untuk mewujudkannya adalah melalui perjanjian multilateral jaminan produk halal yang di dalamnya berisi persyaratan baku, proses pendaftaran satu aplikasi, membentuk badan sertifikasi halal di ASEAN, system akreditasi dan system terpadu sertifikasi halal di ASEAN. Meski panjang proses ini bukan merupakan proses yang mustahil di lakukan di wilayah ASEAN.

Kerjasama regional MEA terkait produk pangan dengan sertifikasi halal di wilayah ASEAN dapat dilakukan melalui perjanjian multilateral yang dilakukan oleh Negara-negara ASEAN, Perjanjian tersebut di dalamnya berisi keseragaman parameter penilaian produk halal di wilayah ASEAN.

Perjanjian Multilateral antara Negara-negara ASEAN terkait sertifikasi halal dapat dirumuskan melalui: 1) Keseragaman syarat utama pemberian sertifikasi halal untuk setiap produk makanan di berbagai Negara ASEAN, 2) Kesepakatan parameter sertifikasi halal demi tercapainya keseragaman sertifikasi produk halal di ASEAN. 3) Kesepakatan system pendaftaran yang tepat. 4) Kesepakatan terkait Keseragaman label halal untuk wilayah ASEAN. 5) Kesepakatan Model pemeriksaan dan pengawasan sertifikasi halan yang memadai untuk setiap Negara di wilayah ASEAN.

Praktik sertifikasi halal di Negara-negara ASEAN memiliki potensi dan memberikan implikasi yang besar bagi Negara ASEAN untuk meningkatkan kerjasama sertifikasi halal, saat ini masing-masing Negara di ASEAN memiliki standar dan praktik yang berbeda dalam pendaftaran sertifikasi halal, berdasarkan hal tersebut perlu adanya kerjasama antara Negara ASEAN untuk menentukan keseragaman, sistem serta Lembaga sertifikasi halal yang memadai untuk wilayah ASEAN ${ }^{39}$.

\footnotetext{
${ }^{39}$ Baharusdin Othman, p.21
} 
Kerjasama sertifikasi halal tidak terbatas hanya satu aspek saja, kerjasama di bidang sertifikasi halal haruslah menyeluruh yang di dalamnya terdapat peran lembaga sertifikasi, keseragaman syarat dan ketentuan berdasarkan Al-quran dan hadist, Logo halal yang dicantumkan, kerjasama di bidang pendaftaran sertifikasi halal yang memudahkan bagi masyarakat, serta pengawasan dan sertifikasi lembaga halal di wilayah ASEAN. ${ }^{40}$

Jika dibandingkan dengan masalah hukum dan perizinan, proses sertifikasi halal lebih diperlukan dalam praktek karena konsumen melihat suatu produk berdasarkan label halal yang terdapat dalam prosuk tersebut, dalam prkateknya pula sertifikasi halal menjadi hal yang terpenting dan harus segera disepakati terkait standar halal, keseragaman, dan kemudahan pendaftaran. ASEAN dapat digunakan sebagai penghubung sertifikasi halal antara Negara di ASEAN dan luar ASEAN, oleh karena itu diperlukan standard an keseragaman dalam syarat perolehan label halal dan kesatuan sistem pendaftaran yang terintegrasi, keseragaman label halal dan kemudahan pendaftaran sertifikasi halal akan membuang keraguan konsumen terkait produk halal yang ada di wilayah ASEAN. ${ }^{41}$

Indonesia dalam rencana kerjasama terkait produk halal telah menyatakan bahwa Kerjasama internasional yang paling utama terkait jaminan produk halal dapat berupa ${ }^{42}: 1$ ) Upaya penilaian kesesuaian, atau pengakuan dari sertifikat halal oleh Negara-negara ASEAN terkait sertifikat halal yang dikeluarkan satu Negara ASEAN, dengan kata lain upaya ini adalah proses saling pengakuan dan saling menerima hasil pemeriksaan sertifikasi halal. 2) Kerjasama internasional dalam bentuk pengakuan timbal balik sertifikat halal akan dilakukan dengan lembaga halal luar negeri yang telah secara resmi bekerja sama dengan BPJPH. Badan halal luar negeri yang BPJPH akan bekerja sama harus dibentuk atau harus diakui oleh pemerintah mereka. 3) Untuk impor produk halal sertifikat halal yang telah dikeluarkan oleh lembaga halal luar negeri yang memiliki kerjasama dengan BPJPH, operator bisnis yang mengimpor produk tidak perlu mengajukan permohonan untuk produk-produk halal sertifikasi dengan BPJPH. Namun, mereka masih perlu mendaftar produk ini dengan BPJPH sebelum distribusi di Indonesia.

Sistem pendaftaran satu aplikasi harus didukung dengan pembentukan lembaga halal ASEAN, dalam Plan of Action for the Asean Cooperation in Halal Food ${ }^{43}$ dinyatakan pembentukan dewan akreditasi halal regional, dalam rencananya lembaga ini memiliki kewenangan dalam akreditasi halal bagi lembaga halal di Negara ASEAN.

Kewenangan dewan akreditasi halal regional dapat ditambah dengan kewenangan terkait pendaftaran halal yaitu: 1) pemeriksaan sertifikasi halal asean. 2) pemberian logo

${ }^{40}$ ibid, p, 22

$4^{41}$ ibid

42 Update on the Implementing Regulations for Indonesia's Halal Product Assurance (HPA) Law, https://www.usasean.org/sites/default/files/uploads/halal_aug_2017.pdf, diunduh. 5 April 2018

43 ibid 
halal asean bagi pendaftar yang sudah memenuhi syarat. 3) sebagai katalisator pendaftaran satu aplikasi kepada Negara-negara ASEAN yang dimintakan pendaftarannya

Harmonisasi sistem sertifikasi dan akreditasi produk halal regional yang direncanakan Plan of Action for the Asean Cooperation in Halal Food dengan rencana-rencana antara lain: 1) pengembangan konsep catatan/proposal pada: 2) pembentukan regional /internasional badan akreditasi Halal. 3) mengembangkan pedoman ASEAN sertifikasi Halal menyelaraskan panduan Nasional Sertifikasi Halal. 4) ASEAN pedoman untuk sertifikasi Halal, mengembangkan prosedur dan daftar periksa untuk pelaksanaan rekan. 5) Review (akreditasi) sistem penilaian kesesuaian, termasuk kriteria untuk pengakuan kesetaraan. 6) menerapkan standar makanan Halal ASEAN yang meluas dan terbaik. 7) praktek-praktek melalui pengembangan kemitraan dengan sektor swasta. ${ }^{44}$

Harmonisasi dan pendaftaran satu aplikasi sertifikasi halal akan memakan waktu dimulai dengan perjanjian multilateral terkait produk halal, pembentukan lembaga (dewan akreditasi halal regional), pembentukan sistem pendaftaran satu aplikasi, keseragaman persyaratan, standar halal, sertifikasi regional, peraturan dan persetujuan.

Saat ini perjanjian bilateral antara dua Negara ASEAN untuk saling mengakui sertifikasi halal dan perjanjian eksport import bahan makanan serta distribusi produk halal masih menjadi upaya antisipatif sebelum dilakukannya kerjasama regional, akan tetapi ASEAN perlu mempercepat pelaksanaan kerjasama harmonisasi sertifikasi halal di ASEAN karena barang dan produk terus beredar di Negara-negara ASEAN, dan yang terpenting adalah memberikan rasa aman untuk konsumen di Negara-negara ASEAN.

\section{Simpulan}

Peredaran barang dan jasa khususnya makanan dalam era masyarakat ekonomi ASEAN menjadi tidak terbendung, banyaknya produk yang masuk ke wilayah Indonesia dengan logo halal yang berbeda dari Negara asal produk menimbulkan keraguan bagi masyarakat islam di indonesia, dengan Sistem sertifikasi halal dengan satu aplikasi dimana satu pengusaha (pendaftar) dapat mendaftar sertifikasi halal di Negara asal, sertifikasi halal di ASEAN (dengan Logo ASEAN) dan berbagai Negara yang dipilih (hingga mendapat logo halal Negara yang dipilih) dengan melibatkan lembaga Dewan Akreditasi Halal regional sebagai katalisator Penyaluran berkas pendaftaran kepada Negara-negara ASEAN yang dimintakan pendaftarannya. Kerjasama negara ASEAN terkait sertifikasi halal seperti pembentukan lembaga (dewan akreditasi halal regional), pembentukan sistem pendaftaran satu aplikasi, keseragaman persyaratan, standar halal,sertifikasi regional, pembentukan peraturan dan persetujuan di bidang sertifikasi halal menjadi solusi yang tepat saat ini untuk memberikan kemudahan bagi para pengusaha sekaligus menjamin keamanan akan produk halal di Indonesia.

${ }^{44}$ PLAN OF ACTION (POA) FOR THE ASEAN COOPERATION IN HALAL FOOD (2017-2020), Adopted 39 th MAF Meeting 28/9/2017, http://asean.org/storage/2012/05/2.-PoA-ASEAN-Halal-Cooperation-2020.pdf 


\section{Daftar Pustaka}

ASEAN Cooperation in Food, Agriculture and Forestry, Asean general Guidelines On The Preparation and Handling of Halal Food, Food Handling Publication Series No.1, http://www.asean.org/storage/images/Community/AEC/AMAF/UpdateApr2014/ASE AN\%20GENERAL\%20GUIDELINES\%20ON\%20HALAL\%20FOOD_.pdf

Baharusdin Othman, Sharifudin Md. Shaaran and Arsiah Bahron, The Potential Of ASEAN in halal Certification Implementation: A Review, Pertanika JournalSocial Science and Humanities, Vol 24 (1), (2016).

Beastudi Indonesia, Halal Village sbagai Bentuk Sentralisasi Industri Pangan Asean dalam kerjasama Masyarakat Ekonomi ASEAN (MEA), https://www.beastudiindonesia.net/ halal-village-sebagai-bentuk-sentralisasi-industri-pangan-asean-dalam-kerjasamamasyarakat-ekonomi-asean-mea/

Bonne, K., \& Verbeke, W. Religious values informing halal meat production and the control and delivery of halal credence quality. Agriculture and Human Values, 25(1), (2008).

Ceranic, S., \& Bozinovic, N. Possibilities and significance of HAS implementation (halal assurance system) in existing quality system in food industry. Journal Biotechnology in Animal Husbandry, 25(3/4) (2009).

Chon Lok Siaw dan Nazayul Shima Abdul Rani, A Critical Review on The Regulatory and Legislation Challenges Faced by Halal Start up SMEs Food Manufacturers in Malaysia. Procedia-Social and Behavioral Sciences, Vol 57, (2012).

Dian Ihsan Siregar, BPOM Ragukan Peredaran Produk Halal di Perdagangan Bebas MEA, http://ekonomi.metrotvnews.com/mikro/yNLy1p2b-bpom-ragukan-peredaranproduk-halal-di-perdagangan-bebas-mea

Economic Research Institute for ASEAN and East Asia, Study on Halal Industry Investment in Brunei Darussalam, Final Report August 2016.

Fuseini, A., Hadley, P. and Knowles, T. (2020), "Halal food marketing: an evaluation of UK halal standards", Journal of Islamic Marketing, Vol. ahead-of-print No. ahead-ofprint. https://remote-lib.ui.ac.id:2116/10.1108/JIMA-02-2020-0037

Hashem Salarzadeh \& Che wan Jasimah, Halal Food Industry in Thailand: History, Prospects and Challenges, Conference: The 1st International Halal Management Conference (Ihmc) 2017; Seoul, Korea

Idris, S.H., Abdul Majeed, A.B. \& Chang, L.W. Beyond Halal: Maqasid al-Shari'ah to Assess Bioethical Issues Arising from Genetically Modified Crops. Sci Eng Ethics 26, 14631476 (2020). https://remote-lib.ui.ac.id:2116/10.1007/s11948-020-00177-6 
Yoghi Arief Susanto, Yeti Sumiyati, Potensi Sertifikasi Halal dalam Menghadapi Masyarakat... | 217

Khadijah Nakyinsige a,d, Yaakob Bin Che Man a,b,Awis Qurni Sazili c," Halal authenticity issues in meat and meat products", Meat Science Journal, vol.91 (2012): 211-212

Kazushi Shimizu, "The ASEAN Charter and the ASEAN Economic Community", Economic Journal of Hokkaido University, Vol 40, (2011).

Majelis Ulama Indonesia, "Sertifikat Halal MUI", http://www.halalmui.org/mui14/index.php/ main/go_to_section/55/136o/page/1,

M.Van der Spiegel, H.J.van Der Fels-Klerx, P. Sterrenburg, S.M.Van Ruth, IMJ. ScholtensToma and E.J. Kok, Halal Assurance In food Supply Chain: Verification of Halal certificates Using Audits and Laboratory Analisis, Trends in Food Science \& technology 27, 2012

Noval Dhwinuari Antony, Kemenag: Rancangan PP Jaminan Produk Halal akan Jadi Landasan BPJH, 16:41, https://news.detik.com/berita/d-3903668/kemenagrancangan-pp-jaminan-produk-halal-akan-jadi-landasan-bpjh.

Plan Of Action (Poa) For The Asean Cooperation In Halal Food (2017-2020), adopted 39 th AMAF Meeting, 28 September 2017, http://asean.org/storage/2012/05/2.-PoAASEAN-Halal-Cooperation-2020.pdf

Pushpanathan Sundram Managing Director, Asia Pacific, EAS Strategies, ASEAN Community: Regional Strategies to Tap Global Halal Business Opportunities, 21 September 2015, http://www.thehalalfood.info/upload/articles/ASEAN_ Pushpanathan.pdf

Ronny Hanitijo Soemitro, Metodologi Penelitian Hukum dan Jurimetri, Jakarta: Ghalia Indonesia. 1990.

Rokshana Shirin Asa, An Overview Of The Developments Of Halal Certification Laws In Malaysia, Singapore, Brunei And Indonesia, Jurnal Syariah, Jil. 27, Bil. 1 (2019)

Shafiq, A, Haque, A.K.M. and Omar, A, Multiple Logos and malay's beliefs : a case of Mix Signal, International Food Research Journal, Vol 22 (4), (2015): 1727-1735

Soerjono Soekanto, et al., Penelitian Hukum Normatif suatu Tinjauan Singkat, Jakarta: Rajawali. 2006.

State of the Global Islamic Economy Report 2020/2021, Thomson Reuters, 2020.

Sumadi, Metode Penelitian, Jakarta: Rajawali Pers. 1988.

Suppanunta Romprasert, "Asian Economic Community with Selected Macroeconomic Variables for Exports Sustainability", International Journal of Economics and Financial Issues, Vol. 3, No. 3, (2013) 
218 | Asy-Syari'ah Vol. 22 No.2, Desember 2020

Susilowati Suparto, et all, Harmonisasi dan Sinkronisasi pengaturan kelembagaan sertifikasi halal terkait pelindungan konsumen muslim di Indonesia, Mimbar Hukum, Vol, No.28 No. 3 (2016)

Syaiful Amri, M. Jamil, Ardiansyah, Analisis Yuridis Kewenangan Majelis Ulama Indonesia dalam penyelenggaraan Jaminal Produk Halal, Fakultas Syari'ah dan Hukum UIN Sumatera Utara Medan, diunduh 7 maret 2020

Undang-Undang No. 33 Tahun 2014 tentang Jaminan Produk Halal (Lembaran Negara Republik Indonesia Tahun 2014 Nomor 295, Tambahan Lembaran Negara Republik Indonesia Nomor 5604).

Vandendriessche, F,"Meat products in the past, today and in the future" "Meat Science Journal, vol.78, No.2, 
Asy-Syari'ah (P-ISSN: 2086-9029 E-ISSN: 2654-5675) is a periodical scientific journal that publishes various results of studies and research, literature review, and other scientific works whose scope covers the field of Islamic law/sharia, law and society in monodisciplinary, interdisciplinary, and multidisciplinary manners. The journal aims to expand and create innovative concepts, theories, paradigms, perspectives and methodologies in the above said scope. The Journal is published twice a year (june and december) by Faculty of Shariah and Law, Sunan Gunung Djati State Islamic University Bandung in collaboration with Asosiasi Sarjana Syariah Indonesia (ASSYI).

\section{EDITORIAL OFFICE:}

Fakultas Syariah dan Hukum UIN Sunan Gunung Djati Bandung J1. Raya A.H. Nasution No. 105 Cibiru Kota Bandung, 40614

Tlp/Fax: +022-7802278 Faks. 022-7802278

Website http://journal.uinsgd.ac.id/index.php/asy-syariah/index

E-mail: Jurnalasy-syariah@uinsgd.ac.id 